\title{
Hodnocení vlivu vzdělání na soběstačnost a mobilitu seniorů
}

\section{Assessing the impact of education on self-sufficiency and mobility of seniors}

\author{
Bohumila Vejrážková
}

Fakulta sportovních studií Masarykovy univerzity, Brno

\begin{abstract}
Abstrakt
Cílem práce je zjistit vliv úrovně dosaženého vzdělání na soběstačnost a mobilitu ve stáři a zmapovat prevalenci omezení soběstačnosti a mobility u seniorů a seniorek. Pro studii byl sestaven náhodný výběr osob starších 75 let, u kterých jsme pomocí Get up and go testu zhodnotili jejich habituální pohyblivost a pomocí Barthel Indexu stanovili úroveň jejich závislosti v ADL (všedních denních činnostech). Prostřednictvím osobnostního dotazníku byla získána personální data o testovaných osobách. Za použití statistických metod jsme porovnali získaná data z testů a osobní údaje o probandech. Sbèr dat a jejich zpracování ještě pokračuje, proto jsou zatím k dispozici jen př̉edběžné závěry.
\end{abstract}

\begin{abstract}
The purpose of this research is to determine the influence of level of education to the self-sufficiency and mobility in seniors, and to map the prevalence of disability and mobility limitations in both elderly men and women. For this study we compiled a random selection of people over 75 years. They were tested with the "Get up and go" test to assess their habitual mobility and by using the Barthel index, we set their level of dependence in ADL (activities of daily living). Through a personality questionnaire, we obtained personal data on the subjects. Using statistical methods, we compared the data obtained from the tests with the personal data from the researched group. Data is still being obtained and processed, therefore we only have preliminary conclusions.
\end{abstract}

Kličová slova: $\quad$ senior, mobilita (habituální pohyblivost), omezení soběstačnosti, vzdělání Key words: $\quad$ senior, mobility, disability, education

\section{Úvod}

Stálý růst počtu osob staršího věku v naší společnosti je provázený vyšší nemocností a potřebou rozsáhlé preventivní i léčebné zdravotnické péče, sociální péče a stále vyšších ekonomických prostředků. Dle demografických údajů dosahoval v roce 2008 počet obyvatel starších 65 let v České republice 1,56 mil, což je téměř 15 procent $\mathrm{z}$ celkového počtu obyvatel. Proto je potřeba uvažovat, jak by bylo možné snížit nemocnost a zlepšit soběstačnost starých lidí, kteří tvoří stále větší procento české populace, a tím snížit náklady na sociální a zdravotní péči.

Jedním z možných řešení je upravit již životní styl mladé generace tak, aby se co nejvíc omezily hlavní rizikové vlivy negativně působící na schopnost aktivního pohybu a soběstačnost ve stárí. Na druhé straně je nutné podporovat zdravé návyky, pohybovou aktivitu a vhodný životní styl v průběhu života. Na ovlivnění těchto faktorů se vedle rodičů velkou měrou podílí škola, která má přispívat $\mathrm{k}$ celkovému rozvoji mladého jedince jak po stránce duševní, tak i fyzické, a usměrňovat jeho postoj ke zdraví a životnímu stylu. Již mladý člověk by se měl snažit, aby si správným životním stylem a návyky zajistil klidné a bezstarostné stárí ve zdraví a duševní pohodě.

Cílem našeho výzkumného šetření je zjistit, jak právě vzdělání ovlivňuje fyzický stav jedince ve stáří. Pro hodnocení fyzického stavu jsme zvolili hodnocení úrovně pohyblivosti a soběstačnosti, které patří k hlavním faktorům kvality života seniorů.

Jak vyplývá z mnohých studií např. Guralnika, souvisí socioekonomické faktory (zejména úroveň vzdělání) jak s celkovou očekávanou délkou života (total life expectancy), tak i s očekávanou délkou 
soběstačného života (Guralnik et al. 1993, Lan T-Y 2002, Melzer 2003). Podobných výsledků dosáhli při svých studiích i Valkonen (1997) a Zunzunegui (2006).

V české literatuře jsme nenašli mnoho zdrojů, které by statisticky dokazovaly vliv socioekonomických faktorů na soběstačnost a mobilitu seniorů v České republice. Mnozí autoři se o tomto vlivu ve svých publikacích zmiňují, např. Pacovský (2000, s. 27) mluví o „dlouhodobé prípravě na stáři“, ve které je rozhodující „celoživotní výchovné, vzdělávací i zdravotně-výchovné pưsobení na celou populaci.“ Nezapomíná ani na důstojné finanční zabezpečení pro budoucí stáří. Holmerová (2006, s. 164) uvádí jako pozitivní faktory snížení disability u seniorů „lepši úroveň vzdělání, zlepšení úrovně bydlení a celkové zlepšení úrovně zdraví populace." Také Georg (1999, s. 98) řadí vzdělání do faktorů ovlivňujících pozitivně funkční věk jedince: „Č́m vyšši je počet let věnovaných vlastnímu školnímu i mimoškolnímu vzdělání a čím vyšši je kvalifikace $v$ dospělém věku, tím přiznivěji je ovlivňováno tempo stárnutí a kvalita funkčního věku.“

Právě pro malé pokrytí tohoto společensky závažného tématu v českých literárních pramenech je cílem naší studie tuto oblast zmapovat a poskytnout statisticky podložené závěry. Ze širokého spektra socioekonomických faktorů jsme pro studii vybrali úroveň dosaženého vzdělání.

\section{Hlavní pojmy:}

\section{Poruchy mobility ve stáŕí}

U stárnoucího organismu dochází $\mathrm{k}$ regresním změnám u řady životně důležitých systémů. Tyto změny př́imo či nepřímo ovlivňují posturu, posturální stabilitu i mobilitu seniora. Zvyšuje se celkový výdej energie na dosažení a udržení vzpř́ímeného postoje (Jančová a Kohlíková, 2007, Daley, 2000). Úbytek svalové hmoty a síly doprovázený degenerativními poruchami pohybového aparátu a chronickými nemocemi (polymorbiditou) seniorů se projevuje na celkové habituální pohyblivosti (mobilitě) jedince.

Poruchy mobility spojené s nepřiměřeně pomalou, obtížnou nebo abnormální chůzí postihují 15-20\% osob starších 65 let a s věkem toto procento ještě stoupá. Asi $1 / 3$ osob nad 75 let jen obtížně zvládá chůzi po schodech a 15-20\% používá pomůcku nebo vyžaduje pomoc druhé osoby. „Vzhledem $k$ zásadní důležitosti pohybu při uspokojování prakticky všech potřeb člověka vede porucha pohyblivosti $k$ poklesu funkčních schopností postiženého, ohrožuje jeho soběstačnost a zhoršuje kvalitu jeho života." (Topinková, Neuwirth, 1996, s. 64)

\section{Testování mobility u seniorů}

Máme k dispozici mnoho testů pro seniory, které mohou určit jejich fyzickou zdatnost, kondici, hbitost a koordinaci. Existují testové baterie (zejména zahraniční) určené pro starší populaci, např. AAHPERD Functional Fitness Test, Groningen Fitness Test nebo Senior Fitness Test. U nás se testováním seniorské populace zabývá zejména Topinková, např. Screeningový test mobility (Topinková, 1996, 2005).

Pro náš výzkum jsme zvolili „Get up and Go Test“ z testové baterie Senior Fitness test (Rikli, Jones, 2001), který nejvíce vyhovuje našemu výzkumnému záměru. Je jednoduchý a v praxi snadno proveditelný, dovoluje získat informace o pohyblivosti a stabilitě testované osoby. V českém překladu ho lze najít v Testovníku - souboru testů pro gerontologii České alzheimerovské společnosti.

\section{Omezení soběstačnosti ve stáří - disabilita}

V Praze byl roku 2006 přijat návrh definice disability dle Mezinárodní klasifikace funkčních schopností, disability a zdraví (MKF): „Disabilita je snižení funkčních schopností na úrovni těla, jedince nebo společnosti, které vzniká, když se občan se svým zdravotním stavem (zdravotní kondicí) setkává s bariérami prostredí." (WHO, 2008)

Guralnik a kol. definují disabilitu jako neschopnost vykonávat nazávisle (samostatně) jednu nebo více základních funkčních činností jako jsou: chůze, osobní hygiena, oblékání, jezení a užívání WC (Guralnik, 1993). 


\section{Testování soběstačnosti u seniorů}

Nejdéle užívané a nejlépe propracované jsou testy používané pro zhodnocení celkových funkčních schopností a úrovně soběstačnosti ADL (activity of daily living) - test základních všedních činností, nazývaný též Barthel Index (Mahoney, Barthel, 1965). Českou verzi přepracovala a standardizovala Topinková. Neuwirth považuje tento test za „...vhodný pro komplexnost a zhodnocení soběstačnosti pacienta." Test ADL je běžně užíván v službách sociální péče, při cílené rehabilitační diagnostice nebo rozhodování o návrhu kompenzačních pomůcek (Topinková, 1996, s. 27).

\section{Cíle a hypotézy \\ Výzkumná otázka:}

Má úroveň dosaženého vzdělání vliv na míru soběstačnosti a habituální pohyblivosti (mobility) u seniorů?

Abychom zodpověděli výzkumnou otázku, stanovili jsme si pro naši práci následující cíle:

\section{Cíle práce}

1. Zmapovat výskyt omezení soběstačnosti a pohyblivosti (mobility) u vybrané skupiny seniorů a porovnat jej se stupněm jejich dosaženého vzdělání.

2. Zmapovat prevalenci omezení mobility a soběstačnosti u seniorů a porovnat je.

3. Zjistit eventuální rozdíly ve výskytu omezení mobility a soběstačnosti mezi pohlavím.

\section{Hypotézy práce}

H1. Vyšší úroveň vzdělání přispívá k zachování soběstačnosti jedince do vyššího věku, než je tomu u jedince s nižším vzděláním.

H2: Vyšší úroveň vzdělání pozitivně ovlivňuje mobilitu ve stáří.

H3: Seniorský věk (stáří) má vliv na zvýšený výskyt omezení soběstačnosti a mobility, přičemž předpokládáme, že výskyt omezení mobility bude vyšší nežli omezení soběstačnosti.

H4: Výskyt omezení soběstačnosti a pohyblivosti není závislý na pohlaví.

\section{Metodologie výzkumu}

Výzkumný soubor:

Do testovaného souboru jsme náhodným výběrem zařadili 60 seniorů (jedná se o prozatímní stav sběru dat), kteří dle definice WHO splňovali věkovou hranici „vlastního stáŕí', tj. $\geq 75$ let. Počet žen v souboru $\mathrm{n}=35$ (věk $=82,3 \pm 2.5$ ), mužů $\mathrm{n}=25$ (věk $=78.1 \pm 1,4$ )

Senioři byli vybráni z několika lokalit v ČR i z různých sociálních tříd - penzion pro seniory (senioři zde žijí samostatně, ale pod dohledem zdravotnických a sociálních pracovníků), nemocniční oddělení LDN, náhodně vybrané domácnosti, senioři navštěvující tělovýchovné sdružení Sokol.

Aktuální fyzický i psychický stav testované osoby musel dovolovat probandovi podstoupit výzkumné šetření. To se týká zejména zdravotního stavu jedince, který by mohl v seniorském věku výrazně ovlivnit výsledky testů. Vyloučili jsme osoby s akutním onemocněním, popř. vážnými zdravotními problémy, které v posledních dnech významně zhoršily zdravotní stav jedince. Také jsme vyloučili osoby, které by pro svůj špatný psychický stav a mentální úroveň nebyly schopny porozumět instruktáži při testování, popř́padě zodpovědět na otázky v dotazníku. Úskalí při výběru výzkumného souboru (upozorňuje na ně Kalvach, 1997, i Pacovský, 1990) spočívá zejména v heterogennosti seniorské populace. Ta je dána „obecně platnou jedinečností schopností a osobnostních vlastností, variabilitou involučních biologických procesů i různou mírou chorobných změn “(Petř́íková, 2004, s. 28). Zároveň se zde projevují sociálně psychologické vlivy.

\section{Výzkumné metody a sběr dat:}

Jedná se o kauzální empirickou korelačně-prediktivní studii. 
K výzkumnému šetření byla použita osobnostní anketa pro získání osobních údajů od testovaných osob (pohlaví, věk, vzdělání, místo bydliště, zdravotní stav...), dále standardizovaný test mobility pro seniory (Get up and go test) a strukturovaný dotazník (Barthel Index - test základních všedních činností) pro hodnocení stupně závislosti testovaných osob.

Na základě odpovědí z ankety byl pak soubor probandů rozdělen 3 skupin: probandi s ukončeným základním vzděláním, středoškolským vzděláním a vysokoškolským vzděláním.

Pro bližší specifikaci a potřeby výzkumu jsme skupinu středoškolsky vzdělaných rozdělili ještě do dvou podskupin a to: středoškolské vzdělání ukončené maturitou a bez maturity (zahrnuje vyučení, některé nástavby nebo rodinné školy). $\mathrm{K}$ tomuto rozdělení nás přiměla skutečnost, že $\mathrm{v}$ úrovni stř̌edoškolského vzdělání existuje rozdíl mezi gymnaziálním studentem a učněm ve výučním oboru, zejména v polovině minulého století, kdy naši probandi studovali.

Rozvržení probandů dle úrovně vzdělání v testovaném souboru znázorňuje Obr. 1.

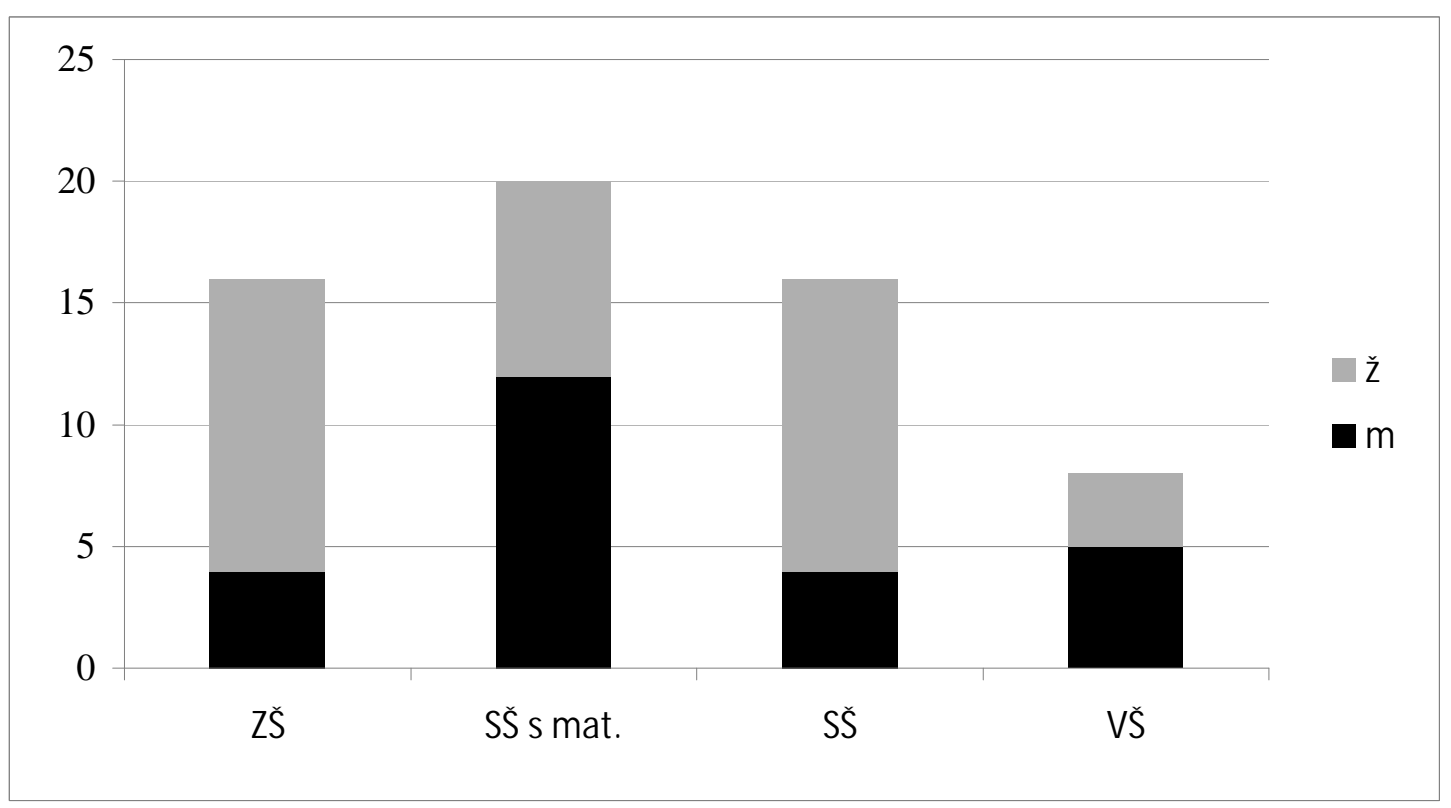

Dalším krokem bylo testování mobility seniorů zvoleným standardizovaným testem Get up and go. Testovaná osoba ze sedu na židli na povel vstane (pokud možno bez pomoci rukou), dojde ke značce vzdálené $3 \mathrm{~m}$ od židle tak rychle, jak je schopna (neběží!), obejde ji a vrátí se k původní židli, na kterou se opět posadí. Sdělíme probandovi, že jeho výkon bude měřen na stopkách. Tento test nám dovoluje posoudit jak stav svalové síly dolních končetin (při zvedání ze židle a dosedání), tak koordinaci a rovnováhu probanda (rovná chůze, otočení kolem kuželu). Pro hodnocení testu je směrodatný jak dosažený čas, tak provedení testu - viz Tab. 1 .

\begin{tabular}{|l|c|c|c|c|}
\hline & $\mathbf{3}$ body & $\mathbf{2}$ body & $\mathbf{1}$ bod & $\mathbf{0}$ bodů \\
\hline Vstane & bez pomoci & s pomocí rukou & s dopomocí druhé osoby & nesvede \\
\hline Chůze & stabilní & s pomůckou, vrávorá & s dopomocí, výrazná nestabilita & nesvede \\
\hline Otočení & jistě & nejisté, zavrávorání & výrazně nejisté, potřeba dopomoci & nesvede \\
\hline Usednutí & bez pomoci & s pomocí rukou či opření & s dopomocí & nesvede \\
\hline
\end{tabular}

Tab 1. Hodnocení provedení Get up and go testu 
K testování soběstačnosti byl použit Barthel Index. Tento mezinárodně užívaný index hodnocení nezávislosti jedince je sestaven ve formě dotazníku. Obsahuje 10 oblastí zahrnujících základní činnosti každodenního života: jezení, přesuny z lůžka na židli, zabezpečení osobní hygieny, koupání, užití toalety, oblékání, kontinence moči a stolice, chůze po rovině $(50 \mathrm{~m})$, chůze po schodech.

Jednotlivé činnosti jsou bodovány 0, 5 či 10 body podle konkrétního návodu (viz Topinková 1996). Proband, který dosáhl 100 bodů, je kvalifikován jako nezávislý na cizí pomoci, tedy plně soběstačný v ADL. Hodnota 95 bodů a méně již značí jistou míru závislosti (disability).

\section{Předběžné výsledky a diskuze}

$\mathrm{V}$ této fázi výzkumu nemáme $\mathrm{k}$ dispozici ještě dostatečné množství dat, aby bylo možné dojít k validním výsledkům, které by se daly hodnotit a diskutovat. Počet probandů, $\mathrm{n}=60$ současně s rozložením hodnot úrovně vzdělání, jak ukazuje obr. 1, nám prozatím nedovolují vyslovit ani žádné závěry.

\section{Předběžné závěry}

V rámci našeho výzkumu se pokoušíme dokumentovat vliv úrovně dosaženého vzdělání na soběstačnost a mobilitu u seniorů $\mathrm{v}$ české populaci. Na základě prostudované literatury jsme dospěli k názoru, že úroveň vzdělání patří mezi důležité sociální faktory pozitivně ovlivňující soběstačný a aktivní život seniorů. Momentální stav našeho výzkumu však nedovoluje toto tvrzení statisticky podložit, nebot nedostatečný počet testovaných osob by výsledek zkresloval. Jsme si vědomi, že při práci se skupinou seniorů pracujeme s nehomogenním souborem, jehož rozmanitosti a pestrosti se nedá vyhnout a proto se snažíme tuto skutečnost kompenzovat vysokým počtem probandů $\mathrm{v}$ testovaném souboru a brát na ní zř̌etel při vyhodnocování výsledků.

$\mathrm{V}$ testovaném souboru se závislost $\mathrm{v}$ ADL (všedních denních činnostech) měřená Barthel Indexem vyskytla u 28,6\% jedinců, zatímco problém s mobilitou jsme pozorovali u 76,1\% testovaných osob. Již $\mathrm{v}$ této fázi výzkumu můžeme pozorovat markantně vyšší podíl omezení pohyblivosti, zatímco soběstačnost zůstává u většiny probandů zachována. Je pochopitelné, že omezení soběstačnosti nastupuje u seniorů později, než je tomu u mobility. Omezení mobility, a to zejména chůze, je spojeno především se zhoršujícím se somatickým stavem jedince vlivem stárnutí a s regresními změnami v pohybovém aparátu a nervosvalovém řízení. Pro soběstačnost a sebeobsluhu máme také v dnešní době k dispozici mnoho kompenzačních pomůcek, které seniorům pomáhají nástup disability oddálit.

Kvůli nevyrovnanému počtu žen a mužů $\mathrm{v}$ testovaném souboru je $\mathrm{v}$ tuto chvíli obtížné hodnotit a porovnávat získané výsledky. Předběžným šetřením jsme zjistili signifikantní rozdíl ve výskytu omezení mobility mezi muži a ženami, větší výskyt se prokázal u žen. U omezení soběstačnosti se rozdíl mezi muži a ženami neprokázal. Rozdíl ve výskytu omezení mobility by mohl být způsoben vyšším průměrným věkem žen v testovaném souboru (ženy 82,3 , muži 76,1).

\section{Seznam literatury:}

Česká alzheimerovská společnost. (2003). Testovník - soubor testů pro gerontologii, 2003, ISBN 80-86541-11-8

DALEY, M.J., SPINKS, W.L. (2000). Excercise, mobility and aging. Sports Med, 29, 2000, s. 1-12.

GREGOR, O. (1999). Stárnout, to je kumšt, Praha: Dům medicíny, 1999. ISBN 80-7631-51-0

GURALNIK et al. (1993). Education status and active life expectancy among older blacks and whites. N Eng J Med. 1993 Jul 8, 329(2), s. 110-116.

HOLMEROVÁ, I., JURAŠKOVÁ, B. et al. (2006). Aktivní stárnutí, ČES GER REV 2006: 4 (3), s. 163-168

JANČOVÁ J., KOHLÍKOVÁ E. (2007). Regresní změny stárnoucího organismu a jejich vliv na posturální stabilitu, Rehabilitace a fyzikální lékařství, č. 4, 2007, s. 155-162.

KALVACH, Z. et al. (1997). Úvod do gerontologie a geriatrie, Karolinum, Praha, 1997, s. 193. ISBN 80-7184-388-0

KALVACH, Z. et al: (2004) Geriatrie a gerontologie. Praha: Grada, 2004. s. 861. ISBN 80-247-0548-6 
MAHONEY, F.I., BARTHEL, D. (1965). Functional evaluation: The Barthel Index. Maryland State Medical Journal 1965, 14, s. 56-61.

MELZER, D., LAN, T-Y., GURALNIK, J.M. (2003). The predictive validity for mortality of the index of mobility-related limitation-results from the EPESE study, Age and Ageing 2003, 32, s. 619-625.

PACOVSKÝ, V. (2000). Proti věku není léku? Úvahy o stárnutí a stárí. Praha: Karolinum, 2000. s. 124. ISBN 80-7184-486-1

PODSIADLO, D., RICHARDSON, S. (1991). The timed "Up and Go": a test of basic functional mobility for frail elderly persons. J Am Geriatr Soc, 1991, 39, s. 142-148.

TOPINKOVÁ, E., NEUWIRTH, J. (1996). Geriatrie pro praktického lékaře, Praha: Grada, 1996. ISBN 80-7169-099-6

TOPINKOVÁ, E. (2005). Geriatrie pro praxi, Praha: Galén, 2005. ISBN 80-7262-365-6

VALKONEN T. et al. (1997). Health expectancy by level of education in Finland. Soc Sci Med, 1997, 44(6): s. 801-8.

World Health Organization (2008). Mezinárodní klasifikace funkčních schopností, disability a zdraví (MKF), Grada Publishing a.s., 2008. ISBN 802471587

ZUNZUNEGUI et al. (2006). Describing prevalence of disability in activities of daily living, functional limitations and poor self-rated health: a 6-year follow-up study in Spain, Aging Clin Exp Res, 2006, 18(5), s. $352-8$.

Internetové zdroje:

1. RIKLI, R.E., JONES C.J.(2001). Senior Fitness Test Manual. Champaign, IL: Human kinetics. 2001. www.humankinetics.com

2. World Health Organization (2008). Disabilities. Geneva, 2001. http://www.who.int/topics/disabilities/ en/ 